\title{
SPRAY DEPOSITION ON MAIZE USING AN ELECTROSTATIC SPRAYER
}

\author{
Heli H. T. de Assunção ${ }^{*}$, João P. A. R. da Cunha ${ }^{2}$, Sérgio M. Silva ${ }^{3}$, Guilherme S. Alves ${ }^{4}$, \\ Ernane M. Lemes ${ }^{2}$
}

${ }^{1 *}$ Corresponding author. Universidade Federal de Mato Grosso/ Rondonópolis - MT, Brasil.
E-mail: heliheros.assuncao@gmail.com | ORCID ID: https://orcid.org/0000-0002-7575-1971

\section{KEYWORDS}

Zea mays, application rate, electrified droplet, spray technology, spray deposition.

\begin{abstract}
It is a well-known fact that the application of pesticides can be improved using an electrostatic spray due to the reduction of the application rate and increase in deposition on plant targets. However, little information exists on the use of such technology in maize crops. Thus, this study is aimed to evaluate the spray deposition on maize resulting from spray application using an electrostatic sprayer in combination with low application rates and different spray compositions. A field experiment was conducted in a randomized block having a $2 \times 2 \times 2$ factorial design with two application rates $\left(95\right.$ and $\left.52 \mathrm{~L} \mathrm{ha}^{-1}\right)$, with or without the spray electrification, and with or without the synthetic adjuvant. The droplet electrification ability, interference of the electrical conductivity of the spray solution, losses of spray solution to the soil, and spray deposition on maize plants were evaluated for two cases of insecticide applications. The Faraday cage method was used to determine the spray electrification ability of the equipment. The spray deposition on plants and the losses to the soil were analyzed using a tracer (food coloring dye) added to the spray solution that was subsequently detected by spectrophotometry. It was seen that the electrostatic sprayer improved the spray application efficiency, which responded positively to the increase in the electrical conductivity of the spray solution. The deposition of the electrified spray solution on the upper third canopy of maize was found to be higher; the spray solution electrification also reduced the losses to the soil, regardless of the application rate.
\end{abstract}

\section{INTRODUCTION}

Maize (Zea mays L.) is one of the most important cereals produced worldwide. During its cultivation, several factors may compromise the potential yield, such as insects, pests, diseases, and weeds. Despite the widespread use of hybrids with resistance to lepidopterans (Lourenção \& Fernandes, 2013), the cultivation of maize still presents severe problems with pest infestations by the fall armyworm (Spodoptera frugiperda (J. E. Smith) (Lepidoptera: Noctuidae) (Tavares et al., 2017b).

The multiplication of $S$. frugiperda is strongly affected by the weather conditions, especially during the hottest and humid periods of the year, and the presence of volunteer plants from previous harvests. These are favorable conditions for the reproduction and spreading of S. frugiperda (Sarmento et al., 2006). Under these conditions, the application of the insecticides occurs in the first phenological maize stages to improve crop protection, but results in higher production costs. Furthermore, successive cultivations of the same crop and the indiscriminate use of pesticides have considerably increased the problems with insect pest resistance (Dal Pogetto et al., 2012).

Chemical control is one of the most important tools of integrated pest management. However, the incorrect uses of this technique such as the inadequate calibration of the spray equipment or faulty practices of cultivation have increased the number of low-efficiency insecticide applications in pest control (Abd-Elhady \& Abd El-Aal, 2011). Thus, new technologies have been investigated to minimize the increasing costs, such as electrostatic spraying, which can greatly improve the spray deposition on plant targets.

${ }^{2}$ Universidade Federal de Uberlândia/ Uberlândia - MG, Brasil.

${ }^{3}$ Universidade Federal dos Vales do Jequitinhonha e Mucuri/ Unaí - MG, Brasil.

${ }^{4}$ University of Nebraska-Lincoln/ North Platte, EUA. 
The use of this technique has already been demonstrated in case of different crops, with results of gain in spray deposition in the order of 0.5 to 2.5 times, and reduced application rates, which represent a higher application efficiency (Laryea \& No, 2005; Patel et al., 2017). However, some studies have not reported any improvement with the applications using an electrostatic sprayer (Bayer et al., 2011), which raises doubts about the efficiency of this technology.

In addition to the application technique, the use of adjuvants also changes the efficiency of deposition by altering the spray physicochemical characteristics and modifying the deposition parameters on the plant target. An adjuvant can be defined as any substance or compound (except water) which has with the property to facilitate, improve efficiency, or reduce the risks of spray application, without any phytosanitary properties (Kissmann, 1998). Adjuvants can also alter the evaporation time, wetness period, droplet size, contact angle, spreading on the leaves, electrical conductivity, potential for hydrogen $(\mathrm{pH})$, and the surface tension of the spray solution to improve the solution deposition on plants (Cunha et al., 2017).

The electrical conductivity variation of the spray solution causes changes in the magnitude of the droplet electrification, consequently affecting how droplets are attracted to the targets and the biological effectiveness of the pesticides (Patel et al., 2017). However, in the case of maize, there is still a lack of information about the gains of spray depositions using an electrostatic sprayer and low carrier volumes. Therefore, the objective of this study was to evaluate the spray deposition on maize using an electrostatic sprayer associated with low application rates and different compositions of spray solutions.

\section{MATERIAL AND METHODS}

The experiment was carried out in the Laboratory of Agricultural Mechanization (LAMEC-ICIAG) and the Capim Branco experimental farm, attached to the Federal University of Uberlândia (Uberlândia, Brazil). The experimental area is situated at an altitude of $842 \mathrm{~m}$, with coordinates of $18^{\circ} 53^{\prime} 23.46^{\prime \prime} \mathrm{S}$ and $48^{\circ} 20^{\prime} 27.46^{\prime \prime} \mathrm{W}$, on a flat topography and Aw climate type (humid tropical with dry winter) (Beck et al., 2018).

The investigation was divided into three studies (tests). The first was performed to determine the electrical conductivity of the spray solutions used; the second was intended to determine the ability of an electrostatic sprayer to electrify the droplets of each spray solution, and the third test was to evaluate the electrostatic spray application of each spray solution (treatments).

\section{Test 1 - Determination of the electrical conductivity of the spray solutions}

Five solutions were evaluated in a completely randomized experimental design: two concentrations of the insecticide fenpropathrin $\left(300 \mathrm{~g} \mathrm{~L}^{-1}\right)-0.89 \mathrm{~mL} \mathrm{~L}^{-1}$ and 1.63 $\mathrm{mL} \mathrm{L}{ }^{-1}$ (field equivalent: 95 or $52 \mathrm{~L} \mathrm{ha}^{-1}$ spray solution); presence or absence of synthetic adjuvant to elevate electrical conductivity $\left(0.05\right.$ or $\left.0 \% \mathrm{v} \mathrm{v}^{-1}\right)$, and a control treatment with the water used in the previous treatments. All spray solutions were replicated four times. The solutions studied are described in Table 1.

TABLE 1. Products and doses used to compose the spray solution treatments.

\begin{tabular}{ccc}
\hline Spray solution & $\begin{array}{c}\text { Insecticide concentration } \\
\left(\mathrm{mL} \mathrm{L}^{-1}\right)\end{array}$ & Synthetic adjuvant (\%, v:v) \\
\hline $95 \mathrm{IN}$ & 0.89 & - \\
$95 \mathrm{IN} \mathrm{SA}$ & 0.89 & 0.05 \\
$52 \mathrm{IN}$ & 1.63 & - \\
$52 \mathrm{IN} \mathrm{SA}$ & 1.63 & 0.05 \\
Water & - & - \\
\hline Formulation & Emulsifiable concentrate: & Suspension: $\mathrm{N}-34.5 \mathrm{~g} \mathrm{~L}^{-1} ; \mathrm{P}_{2} \mathrm{O}_{5}-207 \mathrm{~g} \mathrm{~L}^{-1} ;$ acidulant $-30.8 \mathrm{~g} \mathrm{~L}^{-1} ;$ \\
Composition & fenpropathrin $-300 \mathrm{~g} \mathrm{~L}^{-1}$ & silicone surfactant $-57.5 \mathrm{~g} \mathrm{~L}^{-1}$ \\
\hline
\end{tabular}

IN: insecticide; SA: synthetic adjuvant

The electrical conductivity of the spray solutions was determined according to the methodology used by Assunção et al. (2019a), and measured directly in the solutions using a portable conductivity meter (AKSO, AK59, São Leopoldo, Rio Grande do Sul, Brazil). Before the readings were taken, the equipment was calibrated using standard solutions provided by the device manufacturer.

\section{Test 2 - Quantification of the droplet electrification using mass/charge ratio}

The influence of the spray solutions on the droplet electrification was studied through the analysis of the mass/charge ratio $(\mathrm{Q} / \mathrm{M})$ using a completely randomized experimental design with five treatments (Table 1) and four replications similar to Test 1 .

A tractor hydraulic boom sprayer (FMCopling, JB80 400 BR12, Araraquara, Brazil) with a $12 \mathrm{~m}$-boom, 24 nozzles spaced at $0.5 \mathrm{~m}$ distance, and a $400 \mathrm{~L}$ tank capacity was used. The sprayer was coupled to a tractor of $85 \mathrm{hp}$ (62.5 kW) (Ursus, 2-85, Nova Petrópolis, Brazil). The electrification equipment (SPE, Porto Alegre, Brazil) was installed in the boom with hollow cone tips (SPE 1, flow rate of $0.265 \mathrm{~L} \mathrm{~min}^{-1}$ at $300 \mathrm{kPa}$ ). A working pressure of 300 $\mathrm{kPa}$ was used in all treatments. The equipment operated at $6.95 \mathrm{kV}$ of voltage.

The magnitude of the charge induced on the atomized droplets was determined by the Faraday cage method used by Tavares et al. (2017a). A cylindrical structure (1.2 $\mathrm{mm}$ diameter) of galvanized steel was constructed and wrapped with metallic gauze $(3.033 \mathrm{~mm}$ aperture). The cage was $0.8 \mathrm{~m}$ in diameter and $0.6 \mathrm{~m}$ in length, which enabled it to capture all the spray jets. The output of the sprayer nozzle was maintained at a distance of $0.05 \mathrm{~m}$ from the opening of the cage. The electrical isolation was performed by a wooden rod of $1.6 \mathrm{~m}$ length at a distance of $0.5 \mathrm{~m}$ from the opening of the cage. Five seconds 
after the sprayer was started, the spray solution was sprayed inside the cage for 1 (one) min. After that, the amount of solution sprayed was collected with the aid of a graduated beaker ( $5 \mathrm{~mL}$ precision). The spray solution density was determined by the relation between the mass of the spray solution and the collected volume. The mass of the spray solution that passed inside the cage per unit of time $\left(\mathrm{kg} \mathrm{s}^{-1}\right)$ was also determined. The measurement of the electrical chain present in the atomized droplets was performed by connecting the cage and the soil to a multimeter (Minipa, ET-2517ND, Joinville, Brazil) that measures from 0 to 600 $\mu \mathrm{A}$ with an accuracy of $\pm 0.2 \%$. The grounding of the multimeter was performed by a copper bar buried $2 \mathrm{~m}$ below the soil level, similar to the methodology used by Tavares et al. (2017a). The multimeter readings were made in continuous electrical current, determining the electrical current induced in the droplets sprayed in the cage to verify the relationship between the electrical current and the mass of liquid sprayed $\left(\mathrm{kg} \mathrm{s}^{-1}\right)$, according to the equation: $\mathrm{Q} / \mathrm{M}=$ $\mathrm{i} / \mathrm{m}$, where $\mathrm{Q} / \mathrm{M}=$ mass/charge ratio $\left(\mathrm{mC} \mathrm{kg}^{-1}\right) ; \mathrm{i}=$ electric current of the spray jet $\left(\mathrm{mC} \mathrm{s}^{-1}\right)$, and $\mathrm{m}$ is the liquid flow $(\mathrm{kg}$ $\mathrm{s}^{-1}$ ) (Sasaki et al., 2015).

The environmental conditions were monitored during the application of the treatments using a digital thermo-higroanemometer (Kestrel, 4000, Boothwyn, USA).

\section{Test 3 - Field experiments}

\section{Experimental area}

The field experiment was conducted during the autumn/winter season of 2018. Sowing was performed with the conventional maize hybrid BM709 (Helix Seeds Ltda), sown in planting lines spaced $0.5 \mathrm{~m}$ apart and stand of 65,000 plants $\mathrm{ha}^{-1}$. The amount of fertilizer needed was determined according to the soil analysis and recommendation of the hybrid company.

\section{Experimental design}

The experimental design used was randomized blocks with four replications in a $2 \times 2 \times 2$ factorial scheme, with two application rates $\left(95\right.$ and $52 \mathrm{~L} \mathrm{ha}^{-1}$ ), with or without any droplet electrification and two spray solution compositions (with or without any synthetic adjuvant). Each plot had an area of $40 \mathrm{~m}^{2}$ (10 planting lines with $8 \mathrm{~m}$ length). The useful area for evaluations consisted of 6 central rows, dismissing $2 \mathrm{~m}$ from each edge.

\section{Treatment application}

The application of the treatments was done using the same equipment described previously (Test 2 ). For the treatments without any electrification, the equipment was turned off, and for the treatments with electrification, the equipment was turned on. The working pressure used during the spray application was $300 \mathrm{kPa}$, which was kept constant for all treatments. Variation of the tractor speed was performed to achieve the application rates $\left(95 \mathrm{~L} \mathrm{ha}^{-1}\right.$ or $52 \mathrm{~L} \mathrm{ha}^{-1}$, tractor speed: 3.3 , and $6 \mathrm{~km} \mathrm{~h}^{-1}$, respectively). The applications for the evaluation of spray deposition on plants and losses to the soil were made to control $S$. frugiperda. They were performed 37 and 44 days after sowing (DAS), when the maize was at V8 and V10 vegetative stage, respectively. The spray solutions used were the same as those described in previous tests (Tests 1 and 2).

\section{Spray deposition}

The deposition on maize plants was evaluated using a bright-blue tracer (food coloring) (Duas Rodas, Jaraguá do Sul, Brazil) added to the spray solution at a dose of 400 $\mathrm{g} \mathrm{ha}^{-1}$ for all treatments (the concentration changed for each application rate). The tracer was then detected by absorbance using a spectrophotometer. After the spray solution applications, four maize leaves were collected randomly from each plot, two on the plant upper third (fifth leaf fully open) and two on the lower third of the plant (leaf insertion about $15 \mathrm{~cm}$ above the soil level). After collection, the leaves were packaged separately in plastic bags and stored in a thermal unit for further handling in the laboratory.

The study of the spray solution losses to the soil was estimated by placing of a set of Petri dishes at the front and back of each experimental plot, arranged between the central lines. After the application, the dishes were collected and stored in a thermal unit. In the laboratory, $100 \mathrm{~mL}$ of distilled water was added to the plastic bags containing the leaves. The bags were then agitated for $30 \mathrm{~s}$ for dilution and extraction of the tracer present in the samples. To extract the tracer in Petri plates, a procedure similar to the extraction of the leaves was performed, adding only $10 \mathrm{~mL}$ of distilled water to each plate. The resulting liquid extracted from each sample (leaves or Petri dishes) was deposited in plastic cups, which were placed in an isolated shaded place for 24 h. After $24 \mathrm{~h}$, the absorbance readings were performed in a spectrophotometer $(630 \mathrm{~nm})$ using a tungsten-halogen lamp (Biospectro, SP22, Curitiba, Brazil). The calibration curves obtained from the tracer standard solutions were then used to determine the concentration $\left(\mathrm{mg} \mathrm{L}^{-1}\right)$. The initial concentration of the spray solution and the volume of the dilution samples were used to determine the mass of the tracer retained on the maize leaves. Simultaneously, the leaves had their leaf area measured by a specific scanner (LI-COR, LI-3100C, Lincoln, Nebraska, USA); and with the data of the total deposit and the leaf area of each sample, the quantity of tracer $(\mu \mathrm{g})$ per $\mathrm{cm}^{2}$ of the maize leaves was calculated.

During the field applications, the environmental conditions were monitored using a thermo-higroanemometer (Kestrel, 4000, Boothwyn, USA). For the first application, at $37 \mathrm{DAS}$, the minimum temperature was 27.1 ${ }^{\circ} \mathrm{C}$ and the maximum was $28.3^{\circ} \mathrm{C}$, air relative humidity was between 49.8 and $55.8 \%$, and the wind speed was between 1.8 and $6.6 \mathrm{~km} \mathrm{~h}^{-1}$. For the second application, at $44 \mathrm{DAS}$, the minimum temperature was $22.4^{\circ} \mathrm{C}$ and the maximum was $24.5^{\circ} \mathrm{C}$, air relative humidity of the air between 45.7 and $59.2 \%$, and wind speed was between 1.0 and $4.2 \mathrm{~km} \mathrm{~h}^{-1}$.

\section{Statistical analysis}

All the data were first submitted to tests of normality of distribution of residues by Shapiro Wilk, homogeneity of variances by Levene, and additivity of blocks by Tukey. After presupposition evaluation, the $F$ test of the analysis of variance (ANOVA) was performed. When significant differences were detected by ANOVA, multiple comparisons of means (Tukey's test) were used. All tests considered a probability of $5 \%$ using the statistical program $R$ (R CORE TEAM, 2018). The study of the correlations (Pearson) between the electrical conductivity of the spray solution and the charge-mass ratio was also performed. 


\section{RESULTS AND DISCUSSION}

Test 1 and 2 - Determination of the electrical conductivity of the spray solutions and quantification of the droplet electrification

The use of the insecticide or adjuvant resulted in changes to the electrical conductivity of the spray solutions
(Table 2). The treatments (spray solutions) that attained highest electrical conductivity (EC) values were those with synthetic adjuvants (95 IN SA and 52 IN SA). Since this synthetic adjuvant is also a foliar fertilizer, it contains salts that raise the spray solution conductivity. The EC is affected by the formulation of the products used, mainly by the ions present, concentration, and ionic valence (Cunha et al., 2017).

TABLE 2. Electrical conductivity and charge/mass ration of the sprays.

\begin{tabular}{|c|c|c|}
\hline Spray solution & $\mathrm{EC}\left(\mu \mathrm{S} \mathrm{cm}^{-1}\right)$ & Charge/mass ratio $\left(\mathrm{mC} \mathrm{kg}^{-1}\right)$ \\
\hline $95 \mathrm{IN}$ & $200 \mathrm{~B}$ & $6.62 \mathrm{D}$ \\
\hline 95 IN SA & $216 \mathrm{~A}$ & $8.50 \mathrm{~A}$ \\
\hline $52 \mathrm{IN}$ & $179 \mathrm{C}$ & $7.70 \mathrm{C}$ \\
\hline 52 IN SA & $214 \mathrm{~A}$ & $8.15 \mathrm{~B}$ \\
\hline Water & $173 \mathrm{D}$ & $4.84 \mathrm{E}$ \\
\hline C.V. $(\%)$ & 1.31 & 0.95 \\
\hline$p$ value & $<0.001$ & $<0.001$ \\
\hline
\end{tabular}

Averages followed by similar letters in the column do not differ by Tukey's test $(\mathrm{p}<0.05) .95 \mathrm{IN}$ : water + insecticide $\left(0.89 \mathrm{~mL} \mathrm{~L}{ }^{-1}\right)$; $95 \mathrm{IN} \mathrm{SA}$ : water + inseticide $\left(0.89 \mathrm{~mL} \mathrm{~L}^{-1}\right)+$ adjuvant $(0.05 \% \mathrm{v} / \mathrm{v}) ; 52 \mathrm{IN}$ : water + insecticide $\left(1.63 \mathrm{~mL} \mathrm{~L}^{-1}\right) ; 52 \mathrm{IN} \mathrm{SA}$ : water + inseticide $(1.63 \mathrm{~mL} \mathrm{~L})+$ synthetic adjuvant $(0.05 \% \mathrm{v} / \mathrm{v})$. CV $(\%)=$ coefficient of variation

The EC values are important, especially when using the electrostatic technique for the application of pesticides. According to Patel et al. (2017), higher values of EC are beneficial to this technique because it alters the amplitude of the droplet electrification, which results in a direct impact on the droplet attraction and deposition on targets, consequently improving the biological effectiveness. Sasaki et al. (2015) observed that, in general, the addition of adjuvants to spray solutions can change the values of EC and mass/charge ratio, interfering with the electrostatic spray. A positive correlation between the EC and the charge/mass ratio was observed, which varied according to a linear model (Figure 1). The use of a synthetic adjuvant increased the charge/mass ratio of the spray solution with only insecticide or water spray alone. A similar trend was observed by Assunção et al. (2019b).

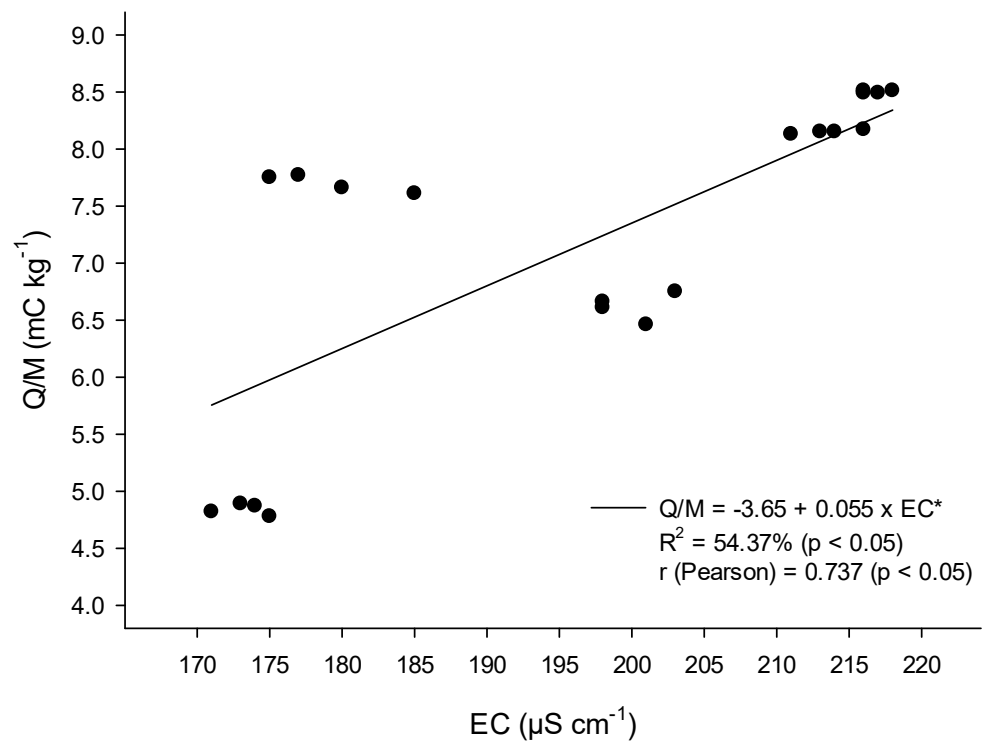

FIGURE 1. Electrical conductivity (EC) and relation charge/mass (Q/M) of the droplets. * Significant $(\mathrm{p}<0.05)$

\section{Test 3 - Field experiments}

\section{Studies on the plant deposition and losses to the soil}

In the first application (37 DAS), the spray deposition in the upper and lower thirds of the maize plants, and the losses to the soil, presented significant differences between the levels of the application technique, and among the spray solutions for the upper third. For the lower third of the plant canopy, a significant interaction between the application technique and the application rate was also seen to occur. For the spray solution losses to the soil, the factor of the application technique presented significant differences. In the second application (44 DAS), the electrostatic technique proved to be significant in the upper third and losses to the soil. In the lower third, the interaction between the factors (application technique and application rate) was significant (Table 3). 
TABLE 3. Analysis of variance (ANOVA, $F$ test) of the spray deposition on maize upper and lower thirds, and losses to the soil in the first and second application.

\begin{tabular}{cccc|ccc}
\hline \multirow{2}{*}{ Factors } & \multicolumn{3}{c|}{ First application (37 DAS) } & \multicolumn{3}{c}{ Second application (44 DAS) } \\
\cline { 2 - 7 } & Upper third & Lower third & Soil & Upper third & Lower third & Soil \\
\hline Technique $(\mathrm{T})$ & $23.08^{* *}$ & $6.02^{*}$ & $4.29^{*}$ & $18.32^{* *}$ & $1.13^{\text {ns }}$ & $5.37^{*}$ \\
Rate $(\mathrm{R})$ & $0.41^{\text {ns }}$ & $7.75^{*}$ & $1.00^{\text {ns }}$ & $1.33^{\text {ns }}$ & $2.49^{\text {ns }}$ & $0.16^{\text {ns }}$ \\
Spray $(\mathrm{S})$ & $4.48^{*}$ & $0.05^{\text {ns }}$ & $0.27^{\text {ns }}$ & $3.52^{\text {ns }}$ & $5.81^{*}$ & $0.69^{\text {ns }}$ \\
$\mathrm{T} \times \mathrm{R}$ & $1.59^{\text {ns }}$ & $0.21^{\text {ns }}$ & $2.34^{\text {ns }}$ & $0.79^{\text {ns }}$ & $5.01^{*}$ & $0.51^{\text {ns }}$ \\
$\mathrm{T} \times \mathrm{S}$ & $0.78^{\text {ns }}$ & $9.12^{* *}$ & $0.43^{\text {ns }}$ & $0.67^{\text {ns }}$ & $0.03^{\text {ns }}$ & $0.43^{\text {ns }}$ \\
$\mathrm{R} \times \mathrm{S}$ & $0.97^{\text {ns }}$ & $5.02^{*}$ & $0.41^{\text {ns }}$ & $1.02^{\text {ns }}$ & $0.18^{\text {ns }}$ & $0.31^{\text {ns }}$ \\
$\mathrm{T} \times \mathrm{R} \times \mathrm{S}$ & $0.21^{\text {ns }}$ & $2.87^{\text {ns }}$ & $<0.01^{\text {ns }}$ & $0.03^{\text {ns }}$ & $0.79^{\text {ns }}$ & $0.28^{\text {ns }}$ \\
\hline
\end{tabular}

Technique: with or without droplet electrification; Rate: rate of application (52 or $\left.95 \mathrm{~L} \mathrm{ha}^{-1}\right)$; spray: with or without synthetic adjuvant.

*: significant $(\mathrm{p}<0.05)$; **: significant $(\mathrm{p}<0.01)$; ${ }^{\text {ns. }}$ non-significant.

The deposition observed by the electrostatic technique in the upper third of the maize plant surpassed the conventional application in almost $50 \%$ of the tracer mass retained in the first application and almost $30 \%$ in the second application (Table 4). These results are in agreement with the results reported by Marques et al. (2019) for the same crop and position in the plant canopy, where the authors achieved an increase of $64 \%$ in the tracer deposition with the use of the electrostatic technique.

TABLE 4. Tracer mass was retained on maize foliage $\left(\mu \mathrm{g} \mathrm{cm}{ }^{-2}\right)$ in the upper third as a function of the application technique (first and second application, 37 and 44 DAS).

\begin{tabular}{lccc}
\hline \multirow{2}{*}{ Application technique } & \multicolumn{2}{c}{ Deposition $\left(\mu \mathrm{g} \mathrm{cm}{ }^{-2}\right)$} \\
\cline { 3 - 4 } Conventional & & First application & Second application \\
Electrostatic & $\mathrm{CV}(\%)$ & $1460 \mathrm{~A}$ & $1033 \mathrm{~B}$ \\
\hline \multicolumn{2}{c}{} & 23.03 & $1334 \mathrm{~A}$ \\
\hline
\end{tabular}

Averages followed by similar letters in the column do not differ by Tukey's test $(\mathrm{p}<0.05)$. CV $(\%)=$ coefficient of variation

The spray deposition as a function of the presence of the synthetic adjuvant is presented in Table 5. Note that the composition of the spray solution was determined for the spray solution deposition, reaching higher values for spray solutions with higher electrical conductivities. This relationship has been studied which demonstrated that the increase in electrical conductivity has an influence on the charge/mass ratio (Sazaki et al., 2015, Patel et al., 2017).

As demonstrated in Figure 1, the increase in the electrical conductivity increases the droplet charge; and higher charges tend to increase the deposition on targets (Assunção et al., 2019b). Increased deposition was also observed in case of the synthetic adjuvant sprayed without electrostatic electrification, since there was no interaction between the application technique and the spray solution. Some other characteristics, such as the surface tension, were seen to improve by using synthetic adjuvant, which allowed the increase of the deposition.

TABLE 5. Tracer mass was retained on maize foliage $\left(\mu \mathrm{g} \mathrm{cm}^{-2}\right)$ in the upper third as a function of the spray solution (first application -37 DAS).

\begin{tabular}{lcc}
\hline & Spray solution & Deposition $\left(\mu \mathrm{g} \mathrm{cm}^{-2}\right)$ \\
\hline $\mathrm{IN}$ & $1116 \mathrm{~B}$ \\
$\mathrm{SA}$ & $1327 \mathrm{~A}$ \\
\hline $\mathrm{CV}(\%)=23.03$ & \\
\hline
\end{tabular}

Averages followed by similar letters in the column do not differ by Tukey's test $(p<0.05)$. IN: water + insecticide; SA: water + inseticide + synthetic adjuvant $(0.05 \% \mathrm{v} / \mathrm{v})$. CV $(\%)=$ coefficient of variation

The spray deposition on the lower third presented a significant interaction between the spray solution and the other two factors (Table 6). The electrostatic technique exceeded the conventional spray application for the lower $\mathrm{EC}$, confirming the increase in deposition of this technique, as discussed previously. It is noteworthy that the water used in the study presented an $\mathrm{EC}$ of $173 \mu \mathrm{S} \mathrm{cm}^{-1}$, which might have contributed to the results achieved. There is also an increased deposition with the addition of a synthetic adjuvant to the conventional application technique, which is possibly linked to the reduction of the surface tension of the spray solution. 
TABLE 6. Tracer mass was retained on maize foliage $\left(\mu \mathrm{g} \mathrm{cm}^{-2}\right)$ in the lower third (first application: $37 \mathrm{DAS}$ ) as a function of the interaction between spray solution, application technique, spray solution, and application rate.

\begin{tabular}{lccc}
\hline \multirow{2}{*}{ Factor of variation } & \multicolumn{2}{c}{ Deposition $\left(\mu \mathrm{g} \mathrm{cm}^{-2}\right)$} \\
\cline { 3 - 4 } & & \multicolumn{2}{c}{ Spray solution } \\
\hline \multirow{2}{*}{ Application technique } & Conventional & SA \\
\hline \multirow{2}{*}{ Application rate $\left(\mathrm{L} \mathrm{ha}^{-1}\right)$} & Electrostatic & $995 \mathrm{bB}$ & $1251 \mathrm{aA}$ \\
& 95 & $1025 \mathrm{aA}$ & $1206 \mathrm{aA}$ \\
\hline $\mathrm{CV}(\%)=18.23$ & 52 & $1408 \mathrm{aA}$ & $1207 \mathrm{aA}$ \\
& &
\end{tabular}

$\mathrm{CV}(\%)=18.23$

Averages followed by similar letters, lowercase in line and uppercase in column, do not differ by Tukey's test $(p<0.05)$. IN: water + insecticide; SA: water + inseticide + synthetic adjuvant $(0.05 \% \mathrm{v} / \mathrm{v})$. CV $(\%)=$ coefficient of variation

The application rate of $95 \mathrm{~L} \mathrm{ha}^{-1}$ without synthetic adjuvant presented a lower deposition than that of the $52 \mathrm{~L}$ $\mathrm{ha}^{-1}$ application rate (Table 6). This indicates a possible loss of the insecticide at high application rates in the absence of the adjuvant. Therefore, the use of adjuvant can mitigate this problem by increasing the adhesion capacity of the spray solution (Kissmann, 1998). The deposition of the spray solution at undesired location can be considered a waste of financial resources for agriculture, in addition to representing an environmental risk. Thus, knowledge about the appropriate application technology for each situation is essential to avoid pesticide loss and environmental contamination (Calore et al., 2015; Mathews, 2014). Electrostatic spraying can improve the droplet deposition on plants, with the advantages of low environmental contamination, reduced application rate, and low operating cost.

Moreover, the electrostatic system has the potential to reduce up to $50 \%$ of the total losses in each application (Zhou et al., 2012). Similar responses of the upper third for the first application were repeated for the lower third in the second application (Table 7). The deposition in this position reached $846 \mu \mathrm{g} \mathrm{cm}^{-2}$ of tracer in the higher EC, and $697 \mu \mathrm{g}$ $\mathrm{cm}^{-2}$ for the lower EC. These results reinforce the possible influence of the EC in applications with electrostatic spray as well as the benefits that the adjuvants may bring to the applications (Kissmann, 1998).

TABLE 7. Tracer mass was retained on maize foliage $\left(\mu \mathrm{g} \mathrm{cm}^{-2}\right)$ in the lower third (second application, 44 DAS) as a function of the interaction between application rate and technique, application rate, and spray solution.

\begin{tabular}{|c|c|c|c|}
\hline \multirow{3}{*}{ Factor of Variation } & & \multicolumn{2}{|c|}{ Deposition $\left(\mu \mathrm{g} \mathrm{cm}^{-2}\right)$} \\
\hline & & \multicolumn{2}{|c|}{ Application rate $\left(\mathrm{L} \mathrm{ha}^{-1}\right)$} \\
\hline & & 95 & 52 \\
\hline \multirow{2}{*}{ Application technique } & Conventional & $690 \mathrm{bB}$ & $867 \mathrm{aA}$ \\
\hline & Electrostatic & 843 aA & $812 \mathrm{aA}$ \\
\hline \multirow{2}{*}{ Spray solution } & IN & \multirow{2}{*}{\multicolumn{2}{|c|}{$\begin{array}{l}697 \mathrm{~B} \\
846 \mathrm{~A}\end{array}$}} \\
\hline & SA & & \\
\hline
\end{tabular}

Averages followed by similar letters, lowercase in line and uppercase in column, do not differ by Tukey's test $(p<0.05)$. IN: water + insecticide; SA: water + inseticide + synthetic adjuvant $(0.05 \% \mathrm{v} / \mathrm{v})$. CV $(\%)=$ coefficient of variation

The comparison between the spray deposition on the upper and lower thirds indicates a high decrease for the second application compared to the first. This decrease can be attributed to a large number of leaves and greater canopy closure in the second application, once the crop was in the V10 phenological stage. Deposition values increased as the spray nozzle was brought closer to the target (Laryea \& No, 2005); additionally, the reduction of spray deposition on the lower third of the plant canopy was reported in a previous study (Cunha et al., 2011). Table 7 also shows that the lowest application rate presented a high soil deposition with the conventional technique, confirming the importance of the use of adjuvants in spray applications.
The increased spray solution deposition on leaves when using the electrostatic technique was also reported by Martin et al. (2019), who examined the penetration of the droplets into the canopy of cotton crops. He concluded that the induction of charge in the droplets increases the deposition at targets closer to the soil level. It was a real challenge to place the spray droplets in the innermost parts of the canopy and pass the droplets through the barrier of the leaves, increasing the coverage of the plant, without causing losses to the soil, as reported by Ozkan et al. (2006). The electrostatic technique, in addition to the improvement in the spray deposition (Tables 4 and 7), also managed to reduce the solution losses to the ground (Table 8). 
TABLE 8. Tracer mass retained on a Petri dish $\left(\mu \mathrm{g} \mathrm{cm}^{-2}\right)$ on the soil as a function of the application technique (first and second application, 37 and 44 DAS).

\begin{tabular}{lccc}
\hline \multirow{2}{*}{ Application technique } & \multicolumn{2}{c}{ Deposition $\left(\mu \mathrm{g} \mathrm{cm}^{-2}\right)$} \\
\cline { 2 - 4 } Conventional & First application & Second application \\
Electrostatic & $\mathrm{CV}(\%)$ & $4424 \mathrm{~B}$ & $3057 \mathrm{~B}$ \\
\hline \multicolumn{2}{c}{} & $3525 \mathrm{~A}$ & $2283 \mathrm{~A}$ \\
\hline
\end{tabular}

Averages followed by similar letters in the column do not differ by Tukey's test $(\mathrm{p}<0.05)$. CV $(\%)=$ coefficient of variation

Losses to the soil in the first and second applications showed that the electrostatic technique decreased the risk of environmental contamination and the waste of spray solution, as demonstrated by other studies (Marques et al., 2019; Zhou et al., 2012). The electrostatic sprayer can create a zone of electromagnetic interference; thus, when the droplets are sufficiently electrified, they tend to follow the trajectory of the electromagnetic field lines that are created due to the difference in the electric potential among the soil, vegetation, and electrified nozzle. This phenomenon reduces the losses of pesticides to the soil because the droplets are directed to plants that are the closest to the ground surface (Appah et al., 2019).

\section{CONCLUSIONS}

The increase in the electrical conductivity of the spray solution with the adjuvant caused an increase in the charge/mass ratio in the electrostatic spray technique.

The electrostatic spray technique can be beneficial to pesticide applications in maize, increasing the deposition in the plant canopy upper third and reducing the losses to the soil. However, in the lower third, the technique also proved to be superior to conventional application.

The decrease in application rate from 95 to $52 \mathrm{~L} \mathrm{ha}^{-1}$ did not result in reduction of the spray deposition on plants.

\section{ACKNOWLEDGEMENTS}

We, the authors, are thankful to the Federal University of Uberlândia (UFU) for providing permission to use their infrastructure and to the Coordination of Improvement of Higher Education Personnel (CAPES) for granting scholarships.

\section{REFERENCES}

Abd-Elhady HK, Abd El-Aal AA (2011) Insecticides resistance detection in field-collected populations of Pectinophora gossypiella (Saunders). American Journal of Biochemistry and Molecular Biology (1):337-348. DOI: https://doi.org/10.3923/ajbmb.2011.337.348

Appah S, Wang P, Ou M, Gong C, Jia W (2019) Review of electrostatic system parameters, charged droplets characteristics and substrate impact behavior from pesticides spraying. International Journal of Agricultural and Biological Engineering 12(2):1-9. DOI:

https://doi.org/10.25165/j.ijabe.20191202.4673

Assunção HHT, Campos SFB, Sousa LA, Lemes EM, Zandonadi CHS, Cunha JPAR (2019a) Adjuvants plus phytosanitary products and the effects on the physicalchemical properties of the spray liquids. Bioscience journal 35(6):1878-1885. DOI:

http://dx.doi.org/10.14393/BJ-v35n6a2019-46994
Assunção HH, Silva SM, Alves GS, Zandonadi CH, Cunha JP (2019b) Electrostatic spraying effect on spray deposition and powdery mildew control in soybean. Engenharia Agrícola 39(6):721-728. DOI: http://dx.doi.org/10.1590/1809-4430-

Eng.Agric.v39n6p721-728/2019

Beck HE, Zimmermann NE, Mcvicar TR, Vergopolan N, Berg A, Wood EF (2018) Present and future KöppenGeiger climate classification maps at 1-km resolution. Scientific Data 1:1-12. DOI: http://dx.doi.org/10.1038/sdata.2018.214

Bayer T, Costa IFD, Lenz G, Zemolin C, Marques LN, Stefanelo MS (2011) Equipamentos de pulverização aérea e taxas de aplicação de fungicida na cultura do arroz irrigado. Revista Brasileira Engenharia Agrícola Ambiental 15(2):192-198. DOI: http://dx.doi.org/10.1590/S1415-43662011000200007

Calore RA, Ferreira MC, Galli JC (2015) Efeitos de adjuvantes no controle de Enneothrips flavens Moulton, 1941 (Thysanoptera: trypidae) na cultura do amendoim. Revista Brasileira de Ciências Agrárias 10(1):74-81. DOI: https://doi.org/10.5039/agraria.v10i1a5043

Cunha JPAR, Alves GS, Marques RS (2017) Tensão superficial, potencial hidrogeniônico e condutividade elétrica de caldas de produtos fitossanitários e adjuvantes. Revista Ciência Agronômica 48(2):261-270. DOI: http://dx.doi.org/10.5935/1806-6690.20170030

Cunha JPAR, Farnese AC, Olivet JJ, Villalba J (2011) Deposição de calda pulverizada na cultura da soja promovida pela aplicação aérea e terrestre. Engenharia Agrícola 31(2):343-351. DOI: https://doi.org/10.1590/S0100-69162011000200014

Dal Pogetto MHFA, Prado EP, Gimenes MJ, Christovam RS, Rezende DT, Aguiar-Junior HO, Costa SIA, Raetano CG (2012) Corn yield with reduction of insecticidal sprayings against fall armyworm Spodoptera frugiperda (Lepidoptera: Noctuidae). Journal of Agronomy 11(1):1721. DOI: https://doi.org/10.3923/ja.2012.17.21

Kissmann KG (1998) Adjuvantes para caldas de produtos fitossanitários. In: Guedes JVC, Dornelles SB (org). Tecnologia e segurança na aplicação de agrotóxicos: novas tecnologias. Departamento de Defesa Fitossanitária, Sociedade de Agronomia de Santa Maria.

Laryea GN, No SY (2005) Effect of fan speed and electrostatic charge on deposition of orchard canopy sprays. Atomization and Sprays 15(2):133-144. DOI: https://doi.org/10.1615/AtomizSpr.v15.i2.20 
Lourenção ALF, Fernandes MG (2013) Evaluation of Cry $1 \mathrm{Ab}$ and Cry1F Bt maize genotypes for the control of Spodoptera frugiperda (J.E. Smith. 1797) (Lepidoptera: Noctuidae) under field conditions. Científica 41(2):164188. DOI: http://dx.doi.org/10.15361/19845529.2013v41n2p164-188

Marques RS, Cunha JPAR, Alves GS, Alves TC, Silva SM, Zandonadi CHS (2019) Control of Dalbulus maidis in maize crop with electrostatic spraying. Bioscience Journal 35(6):1780-1788. DOI: http://dx.doi.org/10.14393/BJv35n6a2019-42088

Martin DE, Latheef MA, López Jr JD (2019)

Electrostatically charged aerial application improved spinosad deposition on early season cotton. Journal of Electrostatics 97:121-125. DOI:

https://doi.org/10.1016/j.elstat.2018.12.005

Ozkan HE, Zhu H, Derksen RC, Guler H, Krause C (2006) Evaluation of various spraying equipment for effective application of fungicides to control Asian soybean rust. Aspects of Applied Biolog. 77. Available: https://pubag.nal.usda.gov/catalog/16392

Patel MK, Praveen B, Sahoo HK, Patel B, Kumar A, Singh M, Nayak MK, Rajan P (2017) An advance air-induced airassisted electrostatic nozzle with enhanced performance. Computers and Electronics in Agriculture 135:280-288. DOI: https://doi.org/10.1016/j.compag.2017.02.010

R CORE TEAM (2018) R: A Language and Environment for Statistical Computing. R Foundation for Statistical Computing.
Sarmento RA, Souza Aguiar RW, Souza RDAS, Vieira SMJ, Oliveira HG, Holtz AM (2006) Revisão da biologia, ocorrência e controle de Spodoptera frugiperda (Lepidoptera, noctuidae) em milho no brasil. Bioscience Journal 18(2):41-48. Available:

http://www.seer.ufu.br/index.php/biosciencejournal/article/ view/6418.

Sasaki RS, Teixeira MM, Santiago H, Madureira RP, Maciel CFS, Fernandes HC (2015) Adjuvantes nas propriedades físicas da calda, espectro e eficiência de eletrificação das gotas utilizando a pulverização eletrostática. Ciência Rural 45(2):274-279. DOI: https://doi.org/10.1590/0103-8478cr20131604

Tavares RM, Cunha JPAR, Alves TC, Alves GS, Silva JER (2017a) Estudo de um sistema de eletrificação de gotas em pulverizador costal pneumático pelo método de gaiola de Faraday. Revista Ceres 64(5):476-485. DOI: https://doi.org/10.1590/0034-737x201764050004

Tavares RM, Silva JER, Alves GS, Alves TC, Silva SM, Cunha JPAR (2017b) Tecnologia de aplicação de inseticidas no controle da lagarta-do-cartucho na cultura do milho. Revista Brasileira de Milho e Sorgo 16(1):30-42. DOI: https://doi.org/10.18512/1980-6477/rbms.v16n1p30-42

Zhou Y, Qi L, Jia S, Zheng X, Meng X, Tang Z, Shen C (2012) Development and application prospects of pneumatic electrostatic sprayer in orchard. Asian Agricultural Research 4(1):78-80. DOI: https://doi.org/10.22004/ag.econ.133110 